\title{
PENERAPAN HEALTH BELIEF MODEL SEBAGAI UPAYA PENCEGAHAN INFEKSI MENULAR SEKSUAL PADA IBU RUMAH TANGGA
}

\author{
Silvia Ari Agustina1, Bhisma Murti², Argyo Demartoto ${ }^{3}$ \\ ${ }^{1}$ Program Studi Kebidanan, Stikes Jenderal Achmad Yani Yogyakarta. Jl. Ringroad Barat Ambarketawang \\ Gamping Sleman, Telp. (0274) 4342000 Email: silvia_ari99@yahoo.com \\ ${ }^{2}$ Fakultas Kedokteran Universitas Sebelas Maret Surakarta. JI. Ir. Sutami 36 A, Kentingan, Surakarta, 57126, \\ Jawa Tengah, Indonesia \\ ${ }^{3}$ Fakultas IImu Sosial dan Politik Universitas Sebelas Maret Surakarta. Jl. Ir. Sutami 36 A, Kentingan, \\ Surakarta, 57126, Jawa Tengah, Indonesia
}

\begin{abstract}
Background: Sexual and reproductive health issues are increasingly of concern world wide among other circumstances related to genital hygiene. Poor genital hygiene will increase the risk of Sexually Transmitted Infections (STIs). Health Belief Model (HBM) is a set of self-perceptions that determines the health behavior of an individual.

Objective: This study aimed to analyze the application of the health belief model with genital hygiene practice of housewives in Cangkringan.

Method: This study employed mixed-methods with sequential explanatories strategy and cross sectional design. A total of 101 housewives, including 2 housewives, 2 husbands, officers of clinics that serve STIs screening and 1 non-governmental organization were recruited using quota sampling. Data were collected with a questionnaire, interviews and were analyzed using linear regression. Triangulation was conducted to achieve validity and reliability.

Results: Genital hygiene had a positive relationship with the perception of vulnerability (b:0.97; $95 \% \mathrm{Cl}: 0.87$ to $1.06 ; p<0.01$ ), self-efficacy (b: $0.02 ; \mathrm{Cl} 95 \%$ : 0.00 to $0.05 ; \mathrm{p} 0.05$ ), and cues to genital hygiene action (b:0,16; $95 \% \mathrm{Cl}: 0.08$ up to $0.23 ; \mathrm{p}<0.01$ ). There was a negative relationship between genital hygiene with the perception of hygiene barriers (b:-0.13; $95 \% \mathrm{Cl}:-0.18$ to $0.09-; p<0.01)$. The linear regression model showed that independent variables altogether contribute to $84.5 \%$ of genital hygiene. Housewives stated that genital hygiene was important, but maintained inappropriate practices, such as frequently use of femininity cleanser, wearing tight underwears, and using pentyliner.
\end{abstract}

Conclusion: There are four components of Health Belief Model associated with genital hygiene.

Keywords: health belief model, genital hygiene

\section{PENDAHULUAN}

Alat reproduksi perempuan merupakan salah satu organ tubuh yang memerlukan perawatan khusus. Kebersihan daerah genital sangat penting untuk membantu menangkal infeksi dan bau. Daerah genital yang lembab, hangat, dan letaknya sangat dekat dengan uretra dan anus, sehingga bakteri dapat tumbuh dengan mudah. ${ }^{(1,2)}$

Higiene genital yang buruk dapat meningkatkan risiko mengalami IMS. Ada beberapa IMS yang disebabkan oleh kurangnya higiene genital seperti trikomoniasis, vaginosis bakterial, kandidiasis, vulvovaginitis, gonore, klamidia, dan sifilis. $^{(3)}$ Salah satu upaya untuk mencegah IMS adalah berusaha untuk tetap membersihkan organ intim dan menjaga kesehatan genital. ${ }^{(4)}$

Lebih dari 1 juta orang terjangkit IMS setiap harinya. Setiap tahun sekitar 500 juta orang mengalami salah satu dari beberapa jenis IMS. IMS memiliki dampak besar pada kesehatan seksual dan reproduksi. IMS juga 
dapat meningkatkan risiko penularan Human Immunodeficiency Virus (HIV) tiga kali lipat atau lebih. ${ }^{(5)}$

Kasus baru HIV di Provinsi Yogyakarta setiap tahun mengalami peningkatan seperti kasus HIV pada tahun 2012 terdapat 272 kasus, kemudian meningkat di tahun 2013 yaitu 489 kasus, dan meningkat lagi di tahun 2014, 614 kasus. Jumlah kasus kumulatif AIDS dari tahun 1987-2013 ada 916 kasus. $^{(6)}$ Puskesmas Cangkringan merupakan salah satu Puskesmas di Kabupaten Sleman yang melayani skreening IMS dan HIV/AIDS.

Health Belief Model merupakan sebuah model psikologi yang dapat digunakan untuk memprediksi sebab munculnya perilaku sehat. $^{(7,8,9)}$ Health Belief Model ini dapat diadaptasi untuk mengeksplorasi berbagai perilaku kesehatan jangka panjang dan jangka pendek, termasuk higiene genital dan penularan IMS. ${ }^{(10)}$

Menurut Rosenstock konsep HBM meliputi persepsi ancaman yang terdiri dari persepsi kerentanan dan persepsi keparahan. Persepsi harapan meliputi persepsi manfaat, persepsi hambatan, efikasi diri, dan stimulus tindakan (cues to

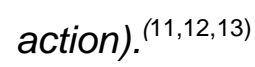

Persepsi ancaman mengacu pada sejauh mana seseorang berpikir tentang penyakit merupakan ancaman kepada dirinya. Asumsinya bahwa, apabila ancaman yang dirasakan tersebut meningkat, maka perilaku pencegahan juga akan meningkat. ${ }^{(14)}$
Persepsi keparahan mempunyai hubungan yang positif dengan perilaku sehat. Jika persepsi keparahan individu tinggi maka individu tersebut akan beperilaku sehat. ${ }^{(11)}$ Teori tersebut sesuai dengan hasil penelitian bahwa semakin tinggi persepsi keparahan terhadap IMS, semakin baik praktiknya dalam pencegahan penyakit IMS. Jika persepsi keparahan IMS tinggi akan menurunkan risiko seseorang mengalami IMS. ${ }^{(15)}$ Hubungan perceived barriers dengan perilaku sehat adalah negatif, jika persepsi hambatan terhadap perilaku sehat tinggi maka perilaku sehat tidak akan dilakukan. ${ }^{(7)}$

Menurut Bandura bahwa self efficacy dapat memengaruhi setiap tingkat dari perubahan pribadi, baik saat individu tersebut mempertimbangkan perubahan kebiasaan yang berkaitan dengan kesehatan. Seseorang akan merasa yakin atas kemampuannya karena kehadiran pengalaman yang berkaitan dengan sebuah perilaku atau merasa yakin berdasarkan observasi yang dilakukan pada orang lain. ${ }^{(12)}$

Persepsi individu dari cues to action diharapkan mampu mendorong adopsi perilaku kesehatan jika individu sudah memegang keyakinan kunci lainnya yang mendukung tindakan. ${ }^{(13)}$ Hasil penelitian yang terdahulu, menunjukkan bahwa WPS cukup aktif mencari informasi IMS melalui teman, petugas kesehatan, penyuluhan, media cetak dan elektronik, tetapi tidak melalui mucikari. $^{(16)}$ 
Perilaku yang kurang baik dalam menjaga kebersihan genitalia dapat meningkatkan risiko terkena IMS dan HIV. ${ }^{(17,18,3,19)}$ Berdasarkan latar belakang tersebut, sangat perlu dilakukan penelitian tentang hubungan penerapan Health Belief Model dengan higiene genitallbu Rumah Tangga di Puskesmas Cangkringan Sleman Yogyakarta. Tujuan dari penelitian ini adalah untuk menganalisis penerapan Health Belief Model dengan higiene genital lbu Rumah Tangga.

\section{BAHAN DAN CARA PENELITIAN}

Desain penelitian ini menggunakan teknik lapangan (field research) dengan jenis penelitian campuran (mixed methodology) dan menggunakan pendekatan cross sectional study. Lokasi penelitian di Puskesmas Cangkringan dengan objek penelitian 101 IRT. Teknik sampling yang digunakan yaitu quota sampling.

Alat pengumpul data kuantitatif adalah kuesioner. Sebelum pengumpulan data, telah dilakukan kajian validitas dan reliabilitas instrumen/kuesioner yang akan digunakan untuk mengukur variabel-variabel yang diteliti. Sehingga kueisoner yang dihasilkan memenuhi syarat minimal konsistensi internal dan selanjutnya digunakan dalam penelitian.

Sedangkan untuk data kualitatif dengan menggunakan wawancara mendalam dengan responden terpilih sesuai dengan kriteria yang ditentukan. Analisis data yang digunakan dalam penelitian ini adalah regresi linier ganda. Sebelum dilakukan uji regresi linier, sebelumnya telah dilakukan uji asumsi klasik sebagai prasyarat uji regresi linier.

\section{HASIL DAN PEMBAHASAN}

Karakteristik objek penelitian mayoritas dalam rentang usia 21-35 tahun (73,3\%). Tingkat pendidikan sebagian besar tingkat menengah/SMA $(59,3 \%)$ dan pendapatan keluarga perbulan mayoritas > UMR Sleman $(57,4 \%)$.

Tabel 1. Hasil Analisis Regresi Linier Ganda

\begin{tabular}{|c|c|c|c|c|}
\hline \multirow[b]{2}{*}{ Variabel Dependen } & \multirow{2}{*}{$\begin{array}{c}\text { Koefisien } \\
\text { Regresi } \\
\text { B }\end{array}$} & \multicolumn{2}{|c|}{$\mathrm{Cl} 95 \%$} & \multirow[b]{2}{*}{$P$} \\
\hline & & $\begin{array}{l}\text { Lower } \\
\text { Bound }\end{array}$ & $\begin{array}{l}\text { Upper } \\
\text { Bound }\end{array}$ & \\
\hline Konstanta & 1,70 & 1,54 & 1,85 & $<0,001$ \\
\hline Persepsi Kerentanan & 0,97 & 0,87 & 1,06 & $<0,001$ \\
\hline Persepsi Keparahan & $-0,01$ & $-0,02$ & 0,01 & 0,349 \\
\hline Persepsi Manfaat Higiene Genital & $-0,01$ & $-0,04$ & 0,03 & 0,763 \\
\hline Persepsi Hambatan Higiene Genital & $-0,13$ & $-0,18$ & $-0,09$ & $<0,001$ \\
\hline Efikasi Diri Higiene Genital & 0,02 & 0,00 & 0,05 & 0,023 \\
\hline $\begin{array}{l}\text { Cues to Action Higiene Genital } \\
\mathrm{N} \text { Observasi }=101 \\
\text { Adjusted } \mathrm{R}^{2}=84,5 \% \\
\mathrm{D}<0.001\end{array}$ & 0,16 & 0,08 & 0,23 & $<0,001$ \\
\hline
\end{tabular}

(Sumber : data primer 2015) 
Sebagai prasyarat menggunakan regresi linier ganda dengan program SPSS 22 dilakukan beberapa jenis diagnosa regresi, antara lain: uji normalitas residu, Multikolinieritas, Heteroskesdatisitas, dan Autokorelasi. Di mana kesemua uji asumsi klasik telah memenuhi syarat sehingga uji regresi linier ganda dapat digunakan.

Berdasarkan hasil analisis multivariat regresi linier pada Tabel 1 dijelaskan hubungan masing-masing variabel independen dengan dependen. Pada variabel persepsi kerentanan, mempunyai hubungan yang positif dengan higiene genital dan secara statistik terdapat hubungan yang sangat signifikan (b:0,97; $\mathrm{Cl}$ 95\%: 0,87 hingga 1,06; $p<0,01)$.

Secara statistik variabel persepsi keparahan tidak mempunyai hubungan dengan higiene genital $(b=-0,01, \mathrm{Cl} 95 \%=-$ $0,02$ hingga $0,01, p=0,349)$. Untuk variabel persepsi manfaat higiene genital secara statistik juga tidak ada hubungan yang signifikan karena nilai $p>0,05(b=-0,01, \mathrm{Cl}$ $95 \%=-0,04$ hingga $0,03, p=0,763$ )

Persepsi hambatan higiene genital mempunyai pengaruh sangat signifikan terhadap perilaku seksual dilihat dari nilai $p<$ 0,01 dan mempunyai hubungan yang negatif dengan higiene genital. Jika terjadi peningkatan hambatan higiene genital, maka akan terjadi penurunan perilaku higiene genital $(b=-0,13, \mathrm{Cl} 95 \%=-0,18$ hingga $-0,09$, $\mathrm{p}<0,01)$.
Efikasi diri mempunyai hubungan yang positif dengan perilaku seksual. Jika terjadi peningkatan efikasi diri perilaku seksual sebesar 1 poin, maka akan terjadi peningkatan 0,02 kali higiene genital yang baik ( $b=0,02, \mathrm{Cl} 95 \%=0,00$ hingga 0,05 , $\mathrm{p}<0,05)$.

Koefisien cues to action perilaku seksual sebesar 0,16 , berarti variabel cues to action perilaku seksual berpengaruh positif terhadap higiene genital dengan nilai $p<0,01$ jadi dapat disimpulkan bahwa, perubahan cues to action higiene geital akan memengaruhi perilaku higiene genital $(b=$ 0,16, Cl 95\%=-0,08 hingga 0,23, $\mathrm{p}<0,01)$.

Adjusted $\mathrm{R}^{2}=84,5 \%$ mengandung arti, secara bersama-sama seluruh variabel independen di dalam regresi linier ini mampu menjelaskan atau memprediksi variasi higiene genital sebesar $84,5 \%$, artinya hanya $15,5 \%$ saja yang dipengaruhi oleh variabel lain yang tidak ada dalam model regresi linier. Nilai $p<0,001$ untuk keseluruhan model mengandung arti, hubungan keseluruhan variabel independen dengan perilaku seksual secara statistik signifikan.

HBM dioperasionalkan ke dalam konstruk-konstruk yang kemudian disusun menjadi kuesioner dengan pilihan jawaban menggunakan skala likert.

\section{Hubungan Persepsi Kerentanan dengan Higiene Genital}

Hasil penelitian menunjukkan bahwa persepsi kerentanan mempunyai hubungan yang signifikan dan sangat erat dengan 
higiene genital (p:0,000). Sedangkan untuk nilai koefisien persepsi kerentanan sebesar 0,97, berarti variabel persepsi kerentanan berpengaruh positif terhadap perilaku seksual. Jika terjadi penurunan persepsi kerentanan maka akan terjadi pula penurunan higiene genital sebesar 0,97. Hasil ini diperkuat dengan teori yang dikemukakan oleh Rosenstock dalam Taylor (2007), bahwa dalam HBM yang menyatakan bahwa semakin merasa berisiko seseorang terhadap suatu penyakit maka tindakan pencegahan yang dilakukan akan semakin baik pula. Hasil ini sesuai dengan hasil penelitian yang dilakukan oleh Widodo (2009) di Lokalisasi Koplak Grobogan, bahwa semakin rendah persepsi kerentanan seseorang, semakin rendah pula upaya pencegahan penyakit. Rosenstock berpendapat bahwa semakin merasa berisiko seseorang terhadap suatu penyakit maka tindakan pencegahan yang dilakukan akan semakin baik pula. ${ }^{(11)}$ Jika upaya pencegahan rendah, akan meningkatkan risiko seseorang terkena IMS. ${ }^{(15)}$ Ny. S meskipun mengaku merasa rentan terkena IMS dan menganggap bahwa menjaga alat kelamin tetap bersih adalah penting, tetapi dalam menjaga kesehatan alat kelaminnya masih kurang tepat, yaitu seperti sering menggunakan pembersih kewanitaan dan kadang menggunakan pasta gigi.

Hubungan Persepsi Keparahan dengan Perilaku Seksual
Persepsi keparahan tidak memengaruhi higiene genital IRT. Hasil tersebut bertentangan dengan pendapat Rogers dalam teori proteksi motivasi yang menyatakan bahwa keparahan yang dirasakan akan memengaruhi niat seseorang dalam melakukan suatu tindakan atau berperilaku, karena tindakan seseorang untuk mencari pengobatan dan pencegahan penyakit didorong oleh ancaman penyakit tersebut. ${ }^{(20)}$ Hasil ini juga diperkuat oleh pendapat Ny. P yang menganggap IMS merupakan penyakit yang parah, tetapi menganggap IMS tidak berhubungan dengan kebersihan alat kelamin. Menurutnya IMS disebabkan karena perilaku seksual yang tidak aman.

\section{Hubungan Persepsi Manfaat dengan Perilaku Seksual}

Hasil penelitian menunjukkan tidak ada pengaruh yang signifikan antara persepsi manfaat higiene genital dengan higiene genital. Hasil ini tidak sesuai dengan hasil penelitian Widodo (2009), bahwa semakin tinggi persepsi manfaat pencegahan terhadap IMS dan HIV\&AIDS semakin baik praktiknya dalam pencegahan penyakit IMS dan HIV\&AIDS. Perceived benefits merupakan persepsi keuntungan yang memiliki hubungan positif dengan perilaku sehat. ${ }^{(11)}$ Hasil ini juga diperkuat oleh pendapat Ny. P yang menganggap bahwa menjaga kebersihan memang sangat penting, tetapi menurutnya kebersihan alat kelamin tidak berhubungan dengan IMS. 


\section{Hubungan Persepsi Hambatan dengan}

\section{Perilaku Seksual}

Persepsi hambatan higiene genital mempunyai pengaruh signifikan terhadap higiene genital dilihat dari nilai $p<0,05$ dan diketahui nilai koefisien $-0,13$, hal ini berarti variabel manfaat perilaku seksual berpengaruh negatif terhadap perilaku seksual. Jika terjadi peningkatan persepsi manfaat higiene genital, maka akan terjadi penurunan higiene genital sebesar 0,13. Menurut Conner dan Norman (2003), hubungan persepsi hambatan dengan perilaku sehat adalah negatif, jika persepsi hambatan terhadap perilaku sehat tinggi maka perilaku sehat tidak akan dilakukan. Hasil wawancara mendalam terhadap Ny. S, mengatakan bahwa tidak ada hal yang menghambat usahanya untuk menjaga alat kelamin, bahkan suaminya tidak mau berhubungan seksual jika alat kelaminnya dalam keadaan kotor. Sehingga selama ini Ny. S senantiasa menjaga alat kelaminnya untuk tetap bersih.

\section{Hubungan Efikasi Diri dengan Perilaku Seksual}

Variabel efikasi diri perilaku seksual berpengaruh positif terhadap higiene genital. Jika terjadi peningkatan efikasi diri higiene genital sebesar 1 poin, maka akan terjadi peningkatan 0,02 kali perilaku higiene genital. Menurut Bandura bahwa self efficacy dapat memengaruhi setiap tingkat dari perubahan pribadi, baik saat individu tersebut mempertimbangkan perubahan kebiasaan yang berkaitan dengan kesehatan. Seseorang akan merasa yakin atas kemampuannya karena kehadiran pengalaman yang berkaitan dengan sebuah perilaku atau ia merasa yakin berdasarkan observasi yang dilakukan pada orang lain. ${ }^{12}$ Ny. S mengatakan bahwa mampu menjaga alat kelaminnya tetap bersih.

\section{Hubungan Cues to Action dengan Perilaku Seksual}

Variabel cues to action higiene genital berpengaruh positif terhadap higiene genital. Jika terjadi peningkatan cues to action higiene genital sebesar 1 poin, maka akan terjadi peningkatan 0,16 higiene genital. Hasil penelitian ini sesuai dengan hasil penelitian Aryani (2015), bahwa keaktifan mencari informasi melalui teman, petugas kesehatan, penyuluhan, media cetak dan elektronik memengaruhi cara menjaga kebersihan higiene. Faktor pencetus untuk bertindak berasal dari faktor internal maupun faktor eksternal antara lain dari sekolah, majalah, koran, televisi, internet, seminar, pelatihan, pengalaman orang lain, pertemuan teman sebaya, petugas kesehatan, dan rumah sakit. ${ }^{(21)}$ Ny. $P$ pernah mencari tahu tentang cara membersihkan alat kelamin dari internet dan merasa malu jika bertanya dengan tenaga medis atau dengan tetangga, karena Ny $P$ menganggap kebersihan alat kelamin menyangkut hal yang intim. Hasil ini sesuai dengan pendapat Prawirohardjo (2009), perawatan genital sangat jarang dilakukan dan dibicarakan khususnya oleh masyarakat 
Indonesia karena terkesan tabu dan jorok. Perawatan kebersihan yang dibicarakan hanya menyangkut hal umum, sedangkan untuk kesehatan alat reproduksi sangat jarang, karena kurang nyaman untuk dibicarakan.

Hasil penelitian multivariat regresi linier ganda, menunjukkan bahwa nilai p:0,000, Adjusted $\mathrm{R}^{2}=84,5 \%, \mathrm{Cl}$ 95\% 1,54-1,85. Artinya persamaan yang diperoleh hanya mampu menjelaskan perilaku seksual sebesar $84,5 \%$, dan $15,5 \%$ saja yang dijelaskan oleh variabel lain yang tidak diteliti dalam penelitian ini. Hal ini menjelaskan bahwa persepsi manfaat higiene genital, persepsi hambatan higiene genital, efikasi diri higiene genital, dan cues to action higiene genital terhadap higiene genital hampir sepenuhnya mengubah perilaku higiene genital ibu rumah tangga karena hanya sisa sebesar $15,5 \%$ yang dijelaskan oleh variabel lain di luar variabel yang disebutkan. Hasil wawancara dengan IRT mengatakan bahwa, IRT masih sering menggunakan pembersih kewanitaan, menggunakan celana dalam yang ketat, dan saat keputihan sering menggunakan pentyliner. Padahal perilaku tersebut dapat meningkatkan tumbuhnya mikroorganisme dan jamur pada alat kelamin, sehingga dapat menyebabkan IMS yang diakibatkan oleh jamur. Persepsi yang kurang tepat, efikasi diri yang kurang, dan cues to action yang rendah tentang higiene genital dapat memengaruhi higiene genital seseorang.
Menurut Conner (2010), persepsi dalam HBM diyakini dapat menentukan kemungkinan individu melakukan perilaku kesehatan. Tindakan khusus yang diambil ditentukan oleh evaluasi alternatif yang tersedia, fokus tentang manfa

at dari perilaku kesehatan,' dan biaya yang dirasakan atau hambatan melakukan perilaku. Oleh karena itu individu yang paling mungkin untuk mengikuti tindakan kesehatan tertentu jika mereka percaya diri mereka rentan terhadap kondisi tertentu dan mereka juga mempertimbangkan bahwa keadaan yang dialami dapat menjadi serius dan percaya bahwa manfaat lebih besar daripada biaya dari tindakan yang diambil untuk melawan ancaman kesehatan.

Menurut Teori HBM, kemungkinan individu akan melakukan tindakan pencegahan tergantung secara langsung pada hasil dari dua keyakinan atau penilaian kesehatan (health beliefs) yaitu ancaman yang dirasakan dari sakit atau luka (perceived threat of injury or illness) dan pertimbangan tentang keuntungan dan kerugian (benefits and costs). ${ }^{(12)}$

\section{KESIMPULAN}

Terdapat hubungan yang positif dan secara statistik signifikan antara Higiene genital dengan 4 variabel independen yang diteliti meliputi persepsi kerentanan, persepsi hambatan, efikasi diri dan cues to action higene genital. Secara bersama-sama seluruh variabel independen di dalam model 
regresi linier ganda ini mampu menjelaskan higiene genital sebesar 84,5\%. Ibu Rumah Tangga menyatakan bahwa higiene genital penting, dan tidak berkaitan langsung dengan Infeksi Menular Seksual, karena penyakit kelamin disebabkan oleh hubungan seks yang tidak aman.

Komponen HBM dihubungkan dengan perilaku kesehatan suami IRT sebagai objek penelitian. Secara metodologis kemungkinan ada variabel lain yaitu modal sosial, yang memengaruhi perilaku kesehatan, sehingga diperlukan penelitian lebih lanjut tentang variabel tersebut yang kemudian dapat dirumuskan model promosi kesehatan tetang pencegahan Infeksi Menular Seksual.

\section{KEPUSTAKAAN}

1. Sharma P. Problem Related to Menstruation Amongst Adolescent Girl, Indian Journal of Pediatrics, 2008. Volume: 75 (2): 125-129. 2008. Diakses: 1 Desember 2015

2. Johnson J. Maintaining Genital Hygiene, 2015. http://www.hygieneexpert. co.uk/ maintaininggenitalhygiene.html. Diakses: 6 Desember 2015

3. Kliegman RM. Essentials of pediatrics.5th Ed.New York: Elsevier, 2007.

4. Irianto K. Kesehatan Reproduksi (Reproductive Health). Bandung: Alfabeta, 2015.

5. WHO. Sexually Transmitted Infections (STIs). WHO Media Centre, 2014. http://www.who.int/mediacentre/factsheet s/fs110/en/. Diakses: 9 Desember 2015

6. Kemenkes RI. Data dan Informasi Tahun 2014 (Profil Kesehatan Indonesia). Jakarta: Kemenkes RI, 2015.

7. Conner M, Norman P. Predicting Health Behaviour, Research and Practice with Social Cognition Model. Buckingham: Open Univeristy Press, 2003.

8. Carpenter D, Christopher J. A MetaAnalysis of the Effectiveness of Health Belief Model Variables in Predicting Behavior. Health Communication, 2010. 25 (8): $661-$ 669. doi:10.1080/10410236.2010.521906 . Diakses: 29 Oktober 2015

9. Glanz K, Bishop, Donald B. The role of behavioral science theory in development and implementation of public health interventions. Annual review of public health. 2010. Volume: 31: 399-418. doi:10.1146/annurev. publhealth.012809.103604. Diakses: 17 November 2015

10. Glanz K, Rimer BK, Lewis FM. Health Behavior and Health Education. Theory, Research and Practice. UI, 2002. Diakses: 1 Desember 2015 San Fransisco: Wiley \& Sons

11. Taylor D, Bury M, Campling N, Carter S, Garfied S, Newbould J, Rennie T. A Review of the use of the Health BeliefModel (HBM), the Theory of Reasoned Action (TRA), the Theory of Planned Behaviour (TPB) and the Trans- 
Theoretical Model (TTM) to study and predict health related behaviour change. Department of Health: National institute for Clinical Excellence, 2007.

12. Smet, B. Psikologi Kesehatan. Grasindo. Jakarta, 1994.

13. Conner M. Chapter 2: Cognitive Determinants of Health Behavior. Handbook of Behavioral Medicine, 2010. Springer Science+Business Media, LLC. DOI 10.1007/978-0-387-09488-5_2. Diakses: 1 Desember 2015

14. Ogden J. Health Psychology. Open University Press Buckingham Philadelphia,1996.

15. Widodo E. Praktik Wanita Pekerja Seksual dalam Pencegahan Penyakit Infeksi Menular Seksual dan HIV/AIDS di Lokalisasi Koplak Grobogan, 2009. Jurnal Promosi Kesehatan Indonesia Volume: 4 (2). Agustus 2009. Diakses: 29 Oktober 2015

16. Aryani D, Mardiana, Ningrum DNA. Perilaku Pencegahan Infeksi Menular Seksual pada Wanita Pekerja Seksual Kabupaten Tegal. Jurnal Kesehatan Masyarakat, 2015. KEMAS Volume: 10 (2) (2015): 160-168. http://journal.unnes.ac.id/nju/index.php/k emas. Diakses: 1 Desember 2015

17. Kemenkes. B-13 Modul Pelatihan Intervensi Perubahan Perilaku: Mitos dan Fakta. Jakarta: Kemenkes RI, 2009a.

18. Michale W, Cowan F. Vaginal discharge causes diagnosis and treatment. In $A B C$ of sexually transmitted infections. BMJ publishing group Itd, 2005. 7: 25-28. Diakses: 17 November 2015

19. Reed BD, Ford K, Wirawan DN. The Bali STD/AIDS Study: Association Between Vaginal Hygiene Practices and STDs Among Sex Workers, 2001. Sex Transm Inf BMJ;77:46-52. http://sti.bmj.com. Diakses: 6 Desember 2015

20. Wallis, LC. Health Behavior. Theoretical Perspectives. Fall, 1997.

21. Khosidah A, Purwanti S. Persepsi Ibu Rumah Tangga Tentang Voluntarry Councelling And Testing (VCT) Terhadap Perilaku Pencegahan HIV-AIDS. Jurnal Ilmiah Kebidanan, 2014. Volume: 5 (2): 67-78. Edisi Desember 2014. Diakses: 1 Desember 2015

22. Prawirohardjo S. IImu Kebidanan. Jakarta: Yayasan Bina Pustaka Sarwono Prawirohardjo, 2009. 